\title{
Characterization of Ethanolic Extract of Streptomyces sp. as a Pancreatic Lipase Inhibitors Produced by Endophytic Streptomyces sp. AEBg12
}

\author{
Lenni Fitri ${ }^{1,2}$, Anja Meryandini ${ }^{3}$, Dyah Iswantini ${ }^{4,5},{ }^{\square}$ Yulin Lestari $^{{ }^{3,5}}$
}

DOI: 10.15294/biosaintifika.v9i2.8907

${ }^{1}$ Graduate School, Bogor Agricultural University, Indonesia

${ }^{2}$ Department of Biology, Faculty of Mathematics and Natural Sciences, Syiah Kuala University, Banda Aceh, Indonesia

${ }^{3}$ Department of Biology, Faculty of Mathematics and Natural Sciences, Bogor Agricultural University, Indonesia

${ }^{4}$ Department of Chemistry, Faculty of Mathematics and Natural Sciences, Bogor Agricultural University, Indonesia

${ }^{5}$ Tropical Biopharmaca Research Center, Bogor Agricultural University, Indonesia

\section{History Article}

Received 24 February 2017 Approved 7 May 2017 Published 17 August 2017

\section{Keywords}

antiobesity; endophyte; pancreatic lipase inhibitor; Streptomyces sp. AEBg12

\begin{abstract}
Endophytic Streptomyces sp. AEBg12 isolated from Zingiber cassumunar (Bangle) is known to produce pancreatic lipase inhibitory compound. However, the characteristics of this active compound has not been reported yet. This study aimed to determine the characteristics of pancreatics inhibitory compound produced by Streptomyces sp. AEBg12 and to assess the role of endophytic actinobacteria in producing pancreatic lipase inhibitor using endophytic-free bangle tissue culture, wild bangle and compared with the activity of Streptomyces sp. AEBg12 endophytes. Supernatant of Streptomyces sp. AEBg12 was extracted using ethanol, ethyl acetate, and n-hexane solvents. Toxicity test was performed using larvae of shrimp Artemia salina. The results showed that the best solvent to obtain pancreatic lipase inhibitor compounds was ethanol. Phytochemical analysis showed that ethanolic extract of endophytic Streptomyces sp. AEBg12 contained flavonoids. $\mathrm{IC}_{50}$ value of ethanol extract was $180.83 \mu \mathrm{g} / \mathrm{ml}$. The result of TLC showed that ethanolic extract of Streptomyces AEBg12 had a blue luminescence band indicated that there were either flavone, flavanones, flavonols or isoflavones. Inhibitory activity of Streptomyces sp. AEBg12 was higher than wild bangle and bangle tissue culture. The information from this study can be be used as a basic data for further characterization of the active compound, which might be developed as an antiobesity agent through its pancreatic lipase inhibitory activity.
\end{abstract}

\section{How to Cite}

Fitri, L., Meryandini, A., Iswantini, D., \& Lestari, Y. (2017). Characterization of Ethanolic Extract of Streptomyces sp. as a Pancreatic Lipase Inhibitors Produced by Endophytic Streptomyces sp. AEBg12. Biosaintifika: Journal of Biology \& Biology Education, 9(2), 177-184.

(C) 2017 Universitas Negeri Semarang
Correspondence Author:

J1 Dramaga, Babakan, Bogor, Jawa Barat 16680

E-mail: yulinlestari@gmail.com
p-ISSN 2085-191X

e-ISSN 2338-7610 


\section{INTRODUCTION}

Obesity is an abnormal excess of gained weight that occurs due to an excessive fat accumulation. It is the result of energy balance disorders where calories that enter the body are more than calories needed. Among all the treatments for obesity, one of the most promising strategies for weight loss is by inhibiting fat absorption using pancreatic lipase. Fat is not directly absorbed by the intestine unless it has been degraded by pancreatic lipase. Many study of this mechanism were performed to determine the effectiveness of natural products as antiobesity agents. Pancreatic lipase is an enzyme secreted by pancreas and contribute in fat digestion (Shin et al., 2003).

Various types of medicinal plants were used to prevent obesity. This knowledge has been passed down from generation to generation based on their custom (Pradono et al., 2011). Zingiber cassumunar (Bangle) is one potential medicinal plants as a lipase inhibitor. Iswantini et al. (2011) reported that $100 \mathrm{ppm}$ of ethanolic extract of bangle rhizomes had the highest inhibitory effect on pancreatic lipase activity (29.17\%). The inhibitory effect was higher than $100 \mathrm{ppm}$ inhibitory effects of Xenical ${ }^{\circledR} /$ orlistat as a positive control, with inhibition percentage at $17.53 \%$.

A part of plants, microbes are also able to produce secondary metabolites as a pancreatic lipase inhibitor, it can be used as an antiobesity drug. Endophytic microbes are microbes that can live in plant tissue and are able to form colonies without harming the host. Most of seed plants could associate with several endophytic microbes which are able to produce bioactive compounds. It was suspected that the bioactive compounds was associated with coevolution or genetic transfer from the host plant to endophytic microbes (Tan \& Zou, 2001). From the preliminary study, a total of 9 isolates of endophytic actinobacteria from bangle which were capable of producing pancreatic lipase inhibitor was obtained. AEBg12 was the isolate which was able to produce the highest pancreatic lipase inhibitor. Based on morphological, microscopic and molecular observation, it was found that isolates of AEBg12 was Streptomyces sp. This study aimed to discover the content of the compound, toxicity values, inhibition values, TLC of ethanolic extract of Streptomyces sp. AEBg12 and the role of endophytic actinobacteria in producing pancreatic lipase inhibitor compared to plant tissue culture, and plant from the nature. However, the characterization of pancreatic lipase inhibitor compounds produced by Streptomyces sp. AEBg12 has not been studied.
This study aimed to determine the characteristics of the ethanolic extract which contained pancreatics inhibitory compound produced by Streptomyces sp. AEBg12, and to assess the role of endophytic actinobacteria in producing pancreatic lipase inhibitor using endophytic- free bangle tissue culture plant, bangle plant from nature, and compared with the activity of endophytic Streptomyces sp. AEBg12 from bangle plant. It is expected that the output of the study can be used as a basic data for further molecular characterization and development of the active compound as an agent for antiobesity which is obtained from indigenous actinobacteria.

\section{METHODS}

Actinobacteria isolate was inoculated into Erlenmeyer flask containing $1000 \mathrm{ml}$ yeast starch broth medium and incubated at $30^{\circ} \mathrm{C}$ for 10 days on a rotary shaker with 150 (Kekuda et al., 2011). The filtrate was collected by centrifugation at $4000 \mathrm{rpm}$ at $4^{\circ} \mathrm{C}$ for $25 \mathrm{~min}$ to separate supernatant and biomass. Supernatant obtained from selected culture was extracted using various solvents to obtain the active compounds. The solvents tested were ethanol, n-hexane and ethyl acetate. Extraction was performed by adding solvent in to supernatant with a ratio of $1: 1$, then they were homogenized using magnetic stirrer for 2 hours to form water fraction and solvent fraction. Solvent fraction then separated and concentrated by rotary evaporator to obtain concentrated fraction. The fraction obtained then used to test the activity as an inhibitor of pancreatic lipase.

Inhibitor of pancreatic lipase activity test was carried out by using method of Etoundi et al. (2010) with some modifications. A total of $800 \mu 1$ of triolein mixture was added into a test tube containing $200 \mu 1$ swine lipase and $200 \mu 1$ sample. The solution was mixed and then the absorbance was measured using UV-Vis spectrophotometer at 450 $\mathrm{nm}$ wavelength. Then, the solution was incubated for $30 \mathrm{~min}$ at $37^{\circ} \mathrm{C}$ and the absorbance was measured as above. The percentage of pancreatic lipase inhibitory activity was calculated by using the formula:

Inhibition of pancreatic lipase $=\mathrm{A}-\mathrm{B} / \mathrm{A} \times 100$ where $\mathrm{A}=$ pancreatic lipase activity, $\mathrm{B}=$ pancreatic lipase activity after incubation

The toxicity test was performed using larvae of Artemia salina. Determination of $\mathrm{IC}_{50}$ values was performed by testing the inhibitory activity of the extracts on a wide range concentrations. After inhibition value of each concentration of the extract was obtained, then the equation 
as a function of the extract concentration and the amount of inhibition produced was made.

Separation of pancreatic lipase inhibitor compounds was performed by using several solvents so that the right eluent could be obtained. The selected eluent then was dried and its predicted components were detected using reprostar 3 Camag integrated with WinCATS software. Detection was performed with UV at a lenght of $254 \mathrm{~nm}$ and $366 \mathrm{~nm}$. Furthermore, the value Retention Factor (Rf) was determined by using WinCATS software with formula:

$\mathrm{Rf}=$ migration distance of the substance/migration distance of the solvent front

To determine the role of endophytic actinobacteria isolates in producing pancreatic lipase inhibitor, plant endophyte-free from tissue culture and bangle derived from nature wer eused. A total of $0.5 \mathrm{~g}$ samples plant was crushed aseptically then it was added by $0.5 \mathrm{ml}$ of phosphate buffer $0.1 \mathrm{M}(\mathrm{pH}$ 8). Then, pancreatic lipase inhibitory activity of supernatant obtained was tested.

\section{RESULTS AND DISCUSSION}

\section{Extraction of pancreatic lipase inhibitor of Streptomyces sp. AEBg12}

Solvents which were used in this study consisted of ethanol, ethyl acetate and n-hexane. Extraction with various solvents are presented in Table 1. Extraction process with three solvent provided varies result for each solvent. The results showed that extraction with ethanol produced the highest yield ( $4.39 \mathrm{~g}$ ) compared to other solvents, followed by ethyl acetate and n-hexane which were 0.48 and $0 \mathrm{~g}$, respectively. The higher amount of pancreatic lipase inhibitor was produced by ethanol extract. It was probably because the ethanol had a high polarity. Ethanol had a low boiling point and it tend to be safe, non-toxic and harmless solvent. N-hexane could cause some negative effects such as disease and air pollution due to the characteristic of hexane which was toxic if it was consumed. In addition, it was a flammable liquid and had a low biodegradability (Azis et al., 2014).

The result showed that the content of polar compounds in supernatant of Streptomyces sp. AEBg12 were relatively larger than semi-polar and non-polar extract. The result is in line with the research done by Yuhernita (2011) that performed an extraction using a polar solvent (methanol), semi-polar (ethyl acetate) and non-polar (n-hexane) in which the content in polar compounds was higher than non-polar compounds. Ethanol extracts and ethyl acetate extracts were tested for their ability to inhibit the activity of pancreatic lipase. The content of the compound which would be extracted should be considered for selecting the solvents (Septiana \& Asnani, 2012). Ethanol was a polar compound, so that another polar compound would be drag into the extract. The using of ethanol as a solvent in leaves extraction could dissolve alkaloid compounds, polyphenols, and flavonoids (Ayini et al., 2014).

Table 1. Yield of extraction of pancreatic lipase inhibitor of Streptomyces sp. AEBg12 with various solvents

\begin{tabular}{cc}
\hline Solvent & Yield $(\mathrm{g})$ \\
\hline n-hexane & 0 \\
Ethyl acetate & 0.48 \\
Ethanol & 4.39 \\
\hline
\end{tabular}

\section{Phytochemical content of Streptomyces sp. AEBg12}

Culture extracts of Streptomyces sp. AEBg12 were chemically analysed for its phytochemical content (Table 2). Major classes of active compounds contained in the extract could obtained through this analysis (Pujiyanto, 2012). Phytochemical analysis results showed that the water extract of Streptomyces sp. AEBg12 derived from bangle contained flavonoids, saponins and steroids, while ethanol and ethyl acetate extracts only contained flavonoids. Saponins and steroids in ethanol and ethyl acetate extract which were not detected probably because the compounds were small or they were not exist in the sample (Iswantini et al., 2011). Flavonoids, saponins and steroids allegedly able to act as pancreatic lipase inhibitor. These all compounds allegedly capable as an inhibitor of pancreatic lipase. The study of Iswantini et al. (2011) stated that the phytochemical analysis of bangle showed that they contained flavonoids, saponins, steroids and tannins. Flavonoids have been shown to inhibit the activity of lipase in vitro, including that contained in the rhizome of bangle. Saponins also proven capable to inhibit lipase activity both in vitro and in vivo. The study of Dzomba \& Musekiwa (2014) showed that flavonoid extract from roots of $D i$ oscorea steriscus could inhibit the activity of pancreatic lipase and $\alpha$-amylase.

\section{Toxicity test of ethanolic extract of Streptomyces sp. AEBg12}

Toxicity test of ethanolic extract of Streptomyces sp. AEBg12 were conducted on larvae of shrimp Artemia salina (Table 3). The table showed that if the concentration is higher, the more sh- 
rimp larvae were dead. The highest concentrations used in this study was $1000 \mu \mathrm{g} / \mathrm{ml}$ where the percentage of mortality reaches $100 \%$ and the lowest concentrations was $50 \mu \mathrm{g} / \mathrm{ml}$ where the percentage of mortality reaches $26.6 \%$. The values of $\mathrm{LC}_{50}$ of ethanol extract was $231.44 \mu \mathrm{g} / \mathrm{ml}$,this means that at small concentrations, this extract was able to eliminate half of larvae $A$. salina population. According to Meyer et al. (1982), an extract was considered as a highly toxic when it had $\mathrm{LC}_{50}$ values below $30 \mu \mathrm{g} / \mathrm{ml}$, considered as a toxic if it had $\mathrm{LC}_{50}$ values around 30 to $1000 \mu \mathrm{g} /$ $\mathrm{ml}$, and considered as a nontoxic if it had $\mathrm{LC}_{50}$ more than $1000 \mu \mathrm{g} / \mathrm{ml}$. It showed that ethanolic extract of Streptomyces sp. AEBg12 were toxic and indicated that ethanolic extract of Streptomyces sp. AEBg12 contained a high bioactive compound.

Table 2. Phytochemical content of Streptomyces sp. AEBg12

\begin{tabular}{lccc}
\hline \multirow{2}{*}{ Compounds } & \multicolumn{3}{c}{ Solvent } \\
& Water & Ethanol & Ethyl acetate \\
\hline Alkaloid & - & - & - \\
Flavonoid & + & ++ & + \\
Tannin & - & - & - \\
Saponin & + & - & - \\
Quinone & - & - & - \\
Steroid & + & - & - \\
Triterpenoid & - & - & - \\
\hline
\end{tabular}

This study used 48 hours old larvae of $A r$ temia salina. Shrimp larvae at the age of 48 hours already had a complete limb so that the testing would be more certain (Muaja et al., 2013). Shrimp larvae toxicity test was performed as a preliminary study to observe the bioactivity potency and toxicity of each sample, so that the concentration of the extract which was safe for the test could be determined (Pradono et al., 2011).

Table 3. $\mathrm{LC}_{50}$ value of ethanolic extract of shrimp larvae

\begin{tabular}{cc}
\hline Concentration $(\mu \mathrm{g} / \mathrm{ml})$ & $\mathrm{LC}_{50}(\%)$ \\
\hline 0 & 0 \\
50 & 26.6 \\
100 & 30 \\
500 & 83.3 \\
1000 & 100 \\
\hline
\end{tabular}

Several researchers had performed the toxicity test using Brine Shrimp Lethality Test (BSLT). Kekuda et al. (2011) reported that iso- late of Streptomyces origin from soil in Agumbe, Karnataka, India had $\mathrm{LC}_{50}$ values at $42.11 \mu \mathrm{g}$ / $\mathrm{ml}$ with the highest concentration used was 1000 $\mu \mathrm{g} / \mathrm{ml}$ with the percentage of mortality reached $100 \%$. Tantithanagorngul et al. (2011) did initial screening of 459 isolates of Streptomyces origin from soil in Thailand. A total of 3 isolates were selected, namely 442, 449 and 145 (2010), they had a strong toxicity activity that is $10,3.5$ and $12.5 \mathrm{mg} / \mathrm{ml}$ respectively.

\section{Pancreatic lipase inhibitory activity assay of extracts Streptomyces sp. AEBg12}

Extract of Streptomyces sp. AEBg12 were tested for inhibitory activity against lipase. The result showed that ethanolic extract of Streptomyces sp. AEBg12 was able to produce the highest inhibition value compared to the ethyl acetate extract of Streptomyces sp. AEBg12 (Table 4). At a concentration of $1000 \mathrm{ppm}$, ethanolic extract of Streptomyces sp. AEBg12 was able to inhibit the activity of pancreatic lipase by $92.78 \%$, while ethyl acetate extract of Streptomyces sp. AEBg12 inhibit by $65.28 \%$. Ethanolic extract of Streptomyces sp. AEBg12 activity was higher compared with orlistat as a positive control that inhibit by $90.28 \%$. This was because the number of secondary metabolites countained in ethanolic extracts of Streptomyces sp. AEBg12 were more compared to ethyl acetate extract of Streptomyces sp. AEBg12. It was probably due to the number of secondary metabolites of lipase inhibitor in ethanol extract was more compared to ethyl acetate extract. These results were in line with Pradono et al. (2010) which reported that ethanolic extract of tamarind leaves at a concentration of $150 \mathrm{ppm}$ was able to inhibit the activity of pancreatic lipase enzymes to hydrolyze oleic acid by $49.0 \%$. Ethanolic extract of tamarind leaves had the highest inhibitory activity than water extract of tamarind leaves and positive control that was act as an orlistat against human pancreatic lipase activity.

Table 4. Lipase inhibitory activity of various extracts of Streptomyces sp. AEBg12 and orlistat

\begin{tabular}{cccc}
\hline $\begin{array}{c}\text { Con- } \\
\text { centra- } \\
\text { tion } \\
\mu \mathrm{g} / \mathrm{ml} 1\end{array}$ & $\begin{array}{c}\text { Extract inhibitory (\%) } \\
\text { Ethyl ac- } \\
\text { etate }\end{array}$ & Ethanol & $\begin{array}{c}\text { Orlistat } \\
(\%)\end{array}$ \\
\hline 100 & $18.89 \pm 1.73$ & $38.33 \pm 3.63$ & $40.56 \pm 1.92$ \\
250 & $29.44 \pm 1.27$ & $57.5 \pm 1.67$ & $47.22 \pm 1.27$ \\
500 & $33.33 \pm 1.67$ & $66.67 \pm 1.67$ & $71.11 \pm 2.68$ \\
750 & $52.5 \pm 0.83$ & $82.78 \pm 2.68$ & $75.56 \pm 1.27$ \\
1000 & $65.28 \pm 2.10$ & $92.78 \pm 1.27$ & $90.28 \pm 0.48$ \\
\hline
\end{tabular}


Mopuri \& Meriga (2014) performed an extraction on Terminalia paniculata using various solvents. The results showed that ethanol extracts which was used to produce pancreatic lipase inhibitory activity had the highest content compared with extracts from another solvent with activity at $75 \%$. Hadrich et al. (2014) also reported that ethanol and methanolic extracts of pomegranate skin were able to inhibit the activity of pancreatic lipase. The highest lipase inhibitor activity $(100 \%)$ was obtained at a concentration of $1 \mathrm{mg} / \mathrm{ml}$ after 30 minutes of incubation. The study of Dzomba \& Musekiwa (2014) showed that flavonoid produced from ethanolic extract of Dioscorea steriscus had a higher lipase inhibitor activity which was $95.88 \%$ compared to ethyl acetate and chloroform extract. Yuniarto et al. (2015) reported that ethanolic extract of kumis kucing leaves were able to inhibit pancreatic lipase up to $63.92 \%$ at $1000 \mu \mathrm{g} / \mathrm{ml}$.

The results also showed that ethanolic extract of Streptomyces sp. AEBg12 at a concentration of $100 \mathrm{ppm}$ could inhibit the pancreatic lipase up to $38.33 \%$, while ethanolic extract of Zingiber cassumunar (bangle) at a concentration of $100 \mathrm{ppm}$ could inhibit lipase inhibitor activity up to $29.17 \%$ (Iswantini et al., 2011). This result indicated that Streptomyces sp. AEBg12 had higher potency than the host plant, but further research was needed using the same substrate and enzyme.

The results also showed that the lower concentration of the extract, the lower its ability to inhibit pancreatic lipase enzyme activity and the higher concentration of the extract, the higher its ability to inhibit pancreatic lipase enzyme activity. These results were in line with other study which stated that ethanolic extract of kumis kucing leaves produced a higher inhibition percentage with the increases of concentration which were 38.55 , $40,44.26,57.5$ and $63.92 \%$ at concentrations of $0.1,1,10,100$ and $1000 \mathrm{ug} / \mathrm{ml}$ (Yuniarto et al., 2015). Based on these points, ethanolic extract of Streptomyces sp. AEBg12 had a greater effect on inhibition of pancreatic lipase activity, so it was possible to be used as an antiobesity drug.

In this study, $\mathrm{IC}_{50}$ values of each extract were determined. It indicated the concentrations of extract and orlistat. The results showed that the lowest $\mathrm{IC}_{50}$ values was obtained from ethanolic extract of Streptomyces sp. AEBg12 that was $180.83 \mu \mathrm{g} / \mathrm{ml}$ while $\mathrm{IC}_{50}$ values of ethyl acetate

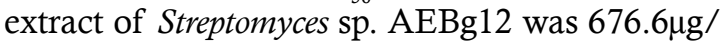
$\mathrm{ml}$ (Figure 1). $\mathrm{IC}_{50}$ value of ethanolic extract of Streptomyces sp. AEBg12 obtained was lower than orlistat $(195.63 \mu \mathrm{g} / \mathrm{ml})$. The results showed that ethanolic extract of Streptomycessp. AEBg12 had pancreatic lipase inhibitory activity which was higher compared to orlistat, so it was possible forfurther development as an antiobesity drug.

Broussonone A that were isolated from the stem barks of Broussonetia kanzinoki showed a noncompetitive inhibitory activity on pancreatic lipase with an $\mathrm{IC}_{50}$ of $28.4 \mu \mathrm{M}$ (Ahn et al., 2012). Buthanol extract of Streptomyces variabilis strain of PO-178 produced pancreatic lipase inhibitor with $\mathrm{IC}_{50}$ of $44.32 \mathrm{mg} / \mathrm{ml}$ (Kekuda \& Onkaroppa, 2014).The study of Adnyana et al. (2014) showed that ethanolic extract of pomegranate leaves inhibited pancreatic lipase with $\mathrm{IC}_{50} 20.64 \mathrm{ug} / \mathrm{ml}$. Syzygium aromaticum extracts could inhibit pancreatic lipase with $\mathrm{IC}_{50}$ value of $0.015 \mathrm{mg} / \mathrm{ml}$.

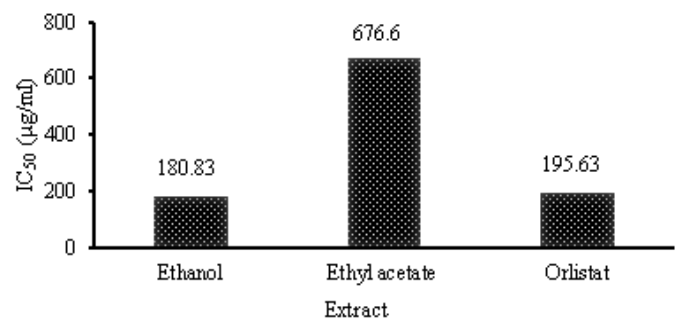

Figure 1. $\mathrm{IC}_{50}$ Values of extract ethanol, ethyl acetate of Streptomyces sp. AEBg12 and orlistat

\section{Profile of TLC (Thin Layer Chromatography) of ethanolic extract Streptomyces sp. AEBg12}

Ethanolic extract of Streptomyces sp. AEBg12 was further fractionated using thin layer chromatography (TLC). TLC was a method to analyze a mixture by separating the compounds which contained in the mixture. TLC method could be used to determine the number of components in a mixture, the identity and the purity of the compounds (Markham, 1988).

TLC testing on this study was also finding a mixed solvent that was able to separate active compounds contained in ethanol extract. From several experiments which has been conducted, eluent that wasable to separate the active components in the extract was indicated by separate bands formed from the result of chromatographic. The band produced from the elution of each eluent was examined under UV light at a wavelengths of 254 and $366 \mathrm{~nm}$. The best eluent which wasable to separate active components of Streptomyces AEBg12 extract was a mixture of methanol:chloroform in the ratio of 9:1. This eluent could separate components contained in the extract into 4 bands with Retention factor (Rf) of $0.03 ; 0.65 ; 0.75 ; 0.76$ (Table 5).

In this study, TLC of orlistat was also 
performed using a mixture solvent containing methanol:chloroform in the ratio of 9:1. The result showed that Streptomyces AEBg12 and orlistat had a different color band. Streptomyces sp. AEBg12 had a blue luminescence band while orlistat has a green luminescence band, this indicated that Streptomyces sp. AEBg12 had different components compounds compared to orlistat (Figure 2). Detection of the components of ethanolic extract of isolate Streptomyces sp. AEBg12 was better observed at a wavelength of $366 \mathrm{~nm}$ than at $254 \mathrm{~nm}$.

Table 5. The result of TLC to determine the best solvent

\begin{tabular}{lcc}
\hline Solvent & $\begin{array}{c}\text { Number } \\
\text { of spot }\end{array}$ & $\begin{array}{c}\text { Rf } \\
\text { Value }\end{array}$ \\
\hline Chloroform : n-hexane $(9: 1)$ & 2 & $0.03 ;$ \\
& & 0.60 \\
n-hexane : ethyl acetate (2:8) & 2 & 0,$04 ;$ \\
& & 0.65 \\
n-hexane : ethyl acetate (3:7) & 2 & $0.03 ;$ \\
& & 0.65 \\
& & $0.03 ;$ \\
Methanol : chloroform (9:1) & 4 & $0.65 ;$ \\
& & $0.75 ;$ \\
& & 0.76 \\
Methanol : chloroform (8:2) & 3 & $0.03 ;$ \\
& & 0.75 \\
Methanol : chloroform (5:5) & 2 & $0.04 ;$ \\
& & 0.9 \\
Methanol : chloroform (3:7) & 3 & $0.07 ;$ \\
& & 0.93 \\
Methanol : chloroform (2:8) & 2 & $0.03 ;$ \\
& & 0.65 \\
& 2 & $0.04 ;$ \\
& & 0.65 \\
\hline
\end{tabular}

According to Markham (1988), blue luminescence band showed on TLC plate when observed at a wavelength of $366 \mathrm{~nm}$ indicating several compounds: flavone, flavanones, flavonols and isoflavones. C-glycoside, a flavone found in leaves of Eremochloa ophiuroides could inhibit pancreatic lipase inhibitor with $\mathrm{IC}_{50}$ values range from 18.5 - $50.5 \mu \mathrm{M}$ (Lee et al., 2010). Galangin, a flavonols found in Alpinia galanga was able to inhibit pancreatic lipase with $\mathrm{IC}_{50} 48.50 \mu \mathrm{M}(\mathrm{Ku}-$ mar \& Alagawadi, 2013).

ImageJ program would convert the band showed on TLC plate into peaks showed in den- sitogram (Fereira \& Rasband, 2012). A high peak indicating high luminescence color on the band on TLC plate. It could be seen that the peak of band 1 was higher than the other band.
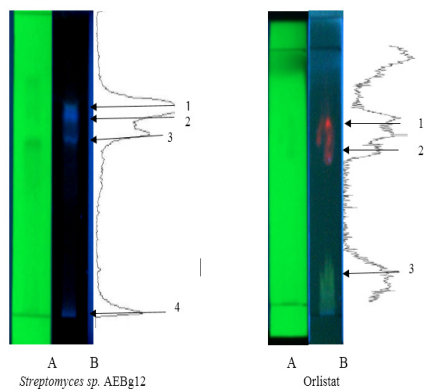

Figure 2. Visualization of thin layer chromatography of ethanolic extract of Streptomyces sp. AEBg12 and orlistat at a wavelength of A) 254 $\mathrm{nm}$ and B) $366 \mathrm{~nm}$

\section{Lipase inhibitor activity of tissue and host plant of Streptomyces sp. AEBg12}

In this study, pancreatic lipase inhibitory activity produced by tissue culture endophytefree bangle, bangle derived from the nature and endophytic actinobacteria were compared (Figure 2). The results were expected to give an overview of the role of the endophytic actinobacteria in producing lipase inhibitor.

The results showed that 2 months old plant tissue culture have a low capability to produce pancreatic lipase inhibitor compound compared to bangle derived from nature and Streptomyces sp. $\mathrm{AEBg} 12$. Inhibition value of plant tissue culture of bangle was $3.3 \%$. Bangle derived from nature produced higher inhibition activity than the tissue culture bangle (23.9\%), but it was lower compared to isolate AEBg12 (95.6\%). The existence of endophytic actinobacteria in bangle which had the ability as a lipase inhibitor was in line with Tan \& Zou (2001) which stated that endophytic microorganisms could produce certain phytochemicals similar to phytochemicals produced by the host plant, and it might be related to the evolution and gene transfer between the endophytic microorganisms with its host.

This results were in line with Pujiyanto (2012) which stated that endophyte-free plant which was obtained from 3 months old plant tissue culture have a low capability to produce inhibitor compound $\alpha$-glucosidase $(0.06 \%)$ compared with Tinospora crispa derived from nature (rod, 1.64; roots, leaves 3.39 and leaves, 4.52\%). However, the ability of $\alpha$-glucosidase inhibitor produced by endophytic actinobacteria BWA65 was higher over the host plant activity (10.98\%). 
Azadirachtin was a biopesticide produced by $\mathrm{Aza}$ dirachta indica that were also found on endophytic fungi (Kusari et al., 2012). Azadirahtin were also detected in induced tissue culture from leaves explants $(2.68 \% \mathrm{DM})$ at the age of 20 weeks and flower explant $(2.48 \% \mathrm{DM})$ at the age of 12 weeks (Veeresham et al., 1998). The presence of pancreatic lipase inhibitor activity in plant tissue culture of bangle has not been reported.

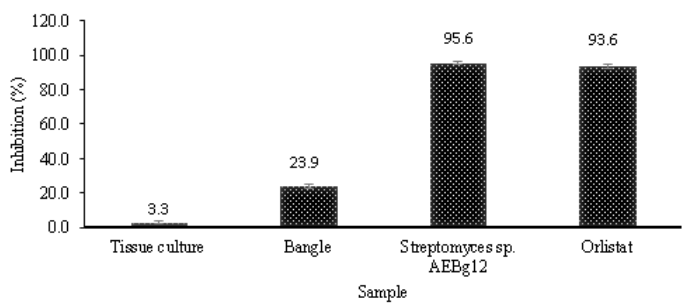

Figure 3. Activity of pancreatic lipase inhibitor produced by tissue culture of bangle, natural plants bangle, and Streptomyces sp. AEBg12.

Based on the data from this study, ethanolic extract of Streptomyces sp. AEBg12 is possibly a new compound that is able to be used as antiobesity drug through the approach to the pancreatic lipase inhibitor. The result also showed that endophytic actinobacteria from plants could produce the same secondary metabolite compounds as the host plants.

\section{CONCLUSIONS}

The results of this study concluded that the water extract of Streptomyces sp. AEBg12, endophytic actinobacteria in bangle contained flavonoids, saponins and steroids while ethanol and ethyl acetate extract contained flavonoids. IC $_{50}$ value of ethanol and ethyl acetate extract were $180.9 \mu \mathrm{g} / \mathrm{ml}$ and $655.3 \mu \mathrm{g} / \mathrm{ml}$ respectively. $\mathrm{IC}_{50}$ value of ethanol extract was lower than orlistat that was $190 \mu \mathrm{g} / \mathrm{ml}$. The result of TLC showed that ethanolic extract of Streptomyces AEBg12 had blue luminescence band indicated that there were either flavone, flavanones, flavonols or isoflavones. Streptomyces sp.AEBg12 produced inhibition value higher than bangle and plant tissue culture of bangle that was $95.6 \%$.

\section{REFERENCES}

Adnyana, I. K., Sukandar, E. Y., Yuniarto, A., \& Finna, S. (2014). Anti-obesity effect of the pomegaranate leaves ethanol extract (Punicagranatum L) in high-fat diet induced mice. International Journal of Pharmacy and Pharmaceutical Sciences, 6(4), 626-631.
Ahn, J. H., Liu, Q., Lee, C., Ahn M. J., Yoo, H. S., Hwang, B. Y., \& Lee M. K. (2012). A new pancreatic lipase inhibitor from Broussonetia kanzinoki. Bioorganic \& Medicinal Chemistry Letters, 22(8), 2760-2763

Arifianti, L., Oktarina, R. D., \& Kusumawati, I. (2014). Pengaruh jenis pelarut pengektraksi terhadap kadar sinensetin dalam ekstrak daun Orthosiphon stamineus Benth. E-Journal Planta Husada, 2(1), 1-4.

Ayini, U., Harnina, B. S., \& Dewi, T. C. (2014). Efek antibakteri ekstrak daun mimba (Azadirachta indica A. Juss) terhadap bakteri Vibrio algynoliticus secara in vitro. Biosaintifika: Journal of Biology \& Biology Education, 6(1), 67-75.

Azis, T., Febrizky, S., \& Mario, A. D. (2014). Pengaruh jenis pelarut terhadap persen yield alkaloid dari daun salam india (Murraya koenigii). Teknik Kimia, 2(20), 1-6.

Dzomba, P., \& Musekiwa, C. (2014). Anti-obesity and antioxidant activity of dietary flavonoids from Dioscorea steriscus tubers. Journal of Coastal Life Medicine, 2(6), 465-470.

Etoundi, C. B., Kuaté, D., Ngondi, J. L., \& Oben, J. (2010). Anti-amylase, anti-lipase and antioxidant effects of aqueous extracts of some Cameroonian spices. Journal of Natural Products, 3, 165-171.

Ferreira, T., \& Rasband, W. (2012). ImageJ user guide IJ 1.46r. National Institute of Health [internet]. Diambil dari http://www.imagej.nih.gov/ij/ docs/guide. diakses 12 Mei, 2016.

Hadrich, F., Cher, S., Gargouri, Y. T., \& Adel, S. (2014). Antioxidant and lipase inhibitory activities and essential oil composition of pomegranate peel extracts. Journal of Oleo Science, 63(5), 515-525.

Iswantini, D., Silitonga, R. F., Martatilofa, E., \& Darusman, L. K. (2011). Zingiber cassumunar, Guazomaulmifolia, and Murraya paniculata extracts as anti-obesity: in vitro inhibitory effect on pancreatic lipase activity. Hayati, 18(1), 6-10.

Kekuda, T. R. P., \& Onkarappa, R. (2014). Antioxidant, antihelmintic and enzyme inhibitory potential of Streptomyces variabilis Strain PO178 Isolated form western ghat soil, Agumbe, Karnataka, India. Journal of Biological Scientific Opinion, 2(2), 170-176.

Kekuda, T. R. P., Shobha, K. S., \& Onkarappa, R. (2011). Pancreatic lipase inhibitory and cytotoxic potential of a Streptomyces species isolated from western ghat soil, Agumbe, Karnataka, India. International Journal of Pharmaceutical and Biological Archives, 2(3), 932-937.

Kumar, S., \& Alagawadi, K. R. (2013). Anti-obesity effects of galangin, a pancreatic lipase inhibitor in cafeteria diet fed female rats. Pharmaceutical Biology, 51(5), 607-613

Kusari, S., Verma, V. C., Lamshoeft, M., \& Spiteller, M. (2012). An endophytic fungus from Azadirachta indica A. Juss.that produces azadirachtin. World Journal of Microbiology and Biotechnology, 28(3), 1287-1294. 
Lee, E. M., Lee, S. S., Chung, B. Y., Cho, J. Y., Lee, I. C., Ahn, S. R., Jang, S. J., \& Kim, T. H. (2010) Pancreatic lipase inhibition by C-Glycosidic flavones isolated from Eremochloa ophiuroides. Molecules, 15(11), 8251-8259.

Markham K. R. (1988). Cara mengidentifikasi flavonoid. Bandung: Penerbit ITB.

Meyer, B. N., Ferrigni, N. R., Putnam, J. E., Jacobsen, L. B., Nichols, D. E., \& McLaughlin, J. L. (1982). Brine shrimp: a convenient general bioassay for active plant constituents. Journal of Medicinal Plants Research, 45(05), 31-34.

Mopuri, R., \& Meriga, B. (2014). Anti-Lipase and antiobesity activities of Terminalia paniculata bark in high calorie diet-induced obese rats. Global Journal of Pharmacology, 8(1), 114-119.

Muaja, A. D., Koleangan, H. S. J., \& Runtuwene, M. R. J. (2013). Uji toksisitas dengan metode BSLT dan analisis kandungan fitokimia ekstrak daun soyogik (Saurauia bracteosa DC) dengan metode soxhletasi. Jurnal Mipa Unsrat, 2(2), 115-118.

Pradono, D. I., Darusman, L. K.,\& Susanti, A. (2011). Inhibisi lipase pankreas secara in vitro oleh ekstrak air dan etanol daun asam jawa (Tamarindus indica) dan rimpang kunci pepet (Kaempferiae rotundae). Jurnal Natur Indonesia, 13(2), 146-154

Pujiyanto, S. (2012). Kajian inhibitor $\alpha$-glukosidase aktinomiset endofit asal brotowali (Tinospora crispa). Disertasi. Bogor: Program Pasca Sarjana. Institut Pertanian Bogor.

Shin, J. E., Han, M. J., \& Kim, D. H. (2003). 3-Methy- lethergalangin isolated from Alpinia officinarum inhibits pancreatic lipase. Biological \& Pharmaceutical Bulletin, 26(6), 854-857.

Septiana, A. T., \& Asnani, A. (2012). Kajian sifat fisikokimia ekstrak rumput laut coklat Sargassum duplicatum menggunakan berbagai pelarut dan metode ekstraksi. Agrointek, 6(1), 22-28.

Tan, R. X., \& Zou, W. X. (2001). Endophytes: a rich source of functional metabolites. Natural Products Reports, 18(4), 448-459.

Tantithanagorngul, W., Sujitwanit, A., Piluk, J., Tolieng, V., Petsom, A., Sangvanich, P., Palaga, T., Puthong, S., Thamchaipenet, A., \& Pinphanichakarn, P. (2011). Screening for brine shrimp larvicidal activity of Streptomyces sp. isolated from soil and anti-tumor activity of the active isolates. Australian Journal of Basic and Applied Sciences, 5(7), 15-22.

Veeresham, C., Kumar, M. R., Sowjanya, D., Kokate, C. K., \& Apte, S. S. (1998). Production of azadirachtin from callus cultures of Azadirachta indica. Fitoterapia, 69(5), 423-424.

Yuhernita, J. (2011). Analisis senyawa metabolit sekunder dari ekstrak metanol daun surian yang berpotensi sebagai antioksidan. Makara Sains, 15(1), 48-52.

Yuniarto, A., Purwani, H., Juanda, D., Setiawan, F., \& Kurnia, I. (2015). Kumis kucing (Orthosiphon stamineus [benth.]) leaves ethanol extract as anti-obesity agent in high-fat diet-induced obese mice. Asian Journal of Pharmaceutical and Clinical Research, 8(6), 234-236. 